\title{
A Model to Estimate Willingness to Pay for Harvest Permits for Wild Edible Mushrooms: Application to Andalusian Forests
}

\author{
Pablo de Frutos ${ }^{1, *}$, Fernando Martinez-Peña ${ }^{2,3,4}$, Jorge Aldea ${ }^{5}$ and Pablo Campos ${ }^{6}$ \\ 1 University of Valladolid. Campus Duques de Soria, Soria 42002, Spain \\ Agrifood Research and Technology Centre of Aragon CITA, Zaragoza 50059, Spain \\ European Mycological Institute (EGTC-EMI), Soria 42003, Spain \\ Micocyl-Junta de Castilla y León-Fundación Cesefor, Soria 42004, Spain; fernando.martinez@cesefor.com \\ 5 Sustainable Forest Management Research Institute University of Valladolid-INIA, Palencia 34004, Spain; \\ jorge.aldea@uva.es \\ 6 Institute for Public Goods and Policies, Spanish National Research Council (CSIC), Madrid 28037, Spain; \\ pablo.campos@cchs.csic.es \\ * Correspondence: pablof@ea.uva.es; Tel.: +349-7512-9318; Fax: +349-7512-9201
}

Academic Editor: Ir. Kris Verheyen

Received: 22 September 2016; Accepted: 18 November 2016; Published: 25 November 2016

\begin{abstract}
Public demand for harvesting wild edible mushrooms has risen in recent decades and currently affects many forested areas around the world. The idea of introducing permits for users has been conceived as a tool for ecosystem management. The problem is that policy-makers lack the necessary means to help guide them when establishing prices for such harvesting permits. Valuing the recreational benefits which mushroom harvesters derive from harvesting wild edible mushrooms may provide certain guidelines as to how much people would be willing to pay and may also justify future payments levied on harvesters. The aim of the present article is to estimate a model for determining citizens' willingness to pay for a harvesting permit in a forest in Andalusia (Spain) using contingent valuation methods. Results show that mean willingness to pay is 22.61 Euros (USD28.18) per harvester and season. This amount depends on several socioeconomic factors and preferences related to harvesters' experiences.
\end{abstract}

Keywords: willingness to pay of harvesters; contingent valuation method

\section{Introduction}

Wild edible mushroom harvesting is now a common activity worldwide. There is a rich relationship between this forest resource and people in many countries like Spain [1,2], Italy [3], Mexico [4,5], Nepal [6], Tanzania [7] or Cameroon [8]. Yet the uses made of this resource, which focus on both traditional and commercial aspects, are shifting towards recreational aspects that involve new activities such as tourism and leisure, most importantly in developed countries like the United States [9], Finland [10], Italy [11] or Spain [12]. The demand function of this activity thus reflects high elasticity in income and the number of recreational harvesters is growing dramatically in many producing areas of these countries [13]. Despite its growing social and economic importance as a forestry resource, the harvesting of wild mushrooms remains a largely neglected issue in forestry management, which has been forced to adapt to the emerging challenges. Various authors have explored the management of mycological resources [14,15], such as the development of mushroom yield models which can be used as a forest management tool to promote wild mushroom production [16,17]. Furthermore, in recent years, some research into mushroom production has been included in forest planning [18-21], highlighting the economic value and importance of this resource. 
Managing wild edible mushrooms is, however, more complex than managing other forest resources, since it involves many factors that are absent from conventional forestry practices. Firstly, ownership rights and markets are not well defined or implemented [22]. For example, tree owners are entitled to all the returns said resource provides whereas the difference between mushroom harvesters and mushroom owners causes serious conflicts between harvesters who lack ownership rights over the mushrooms collected and ownership of trees (and mushrooms), which sparks management problems in many cases. Although national legal systems in many countries recognize land property rights either fully or only partly, harvesters are usually able to obtain the bulk of the revenue for free. There are numerous solutions to the problem of ownership rights of wild edible mushrooms [23], ranging from their consideration as pure public goods, as is the case in northern European countries (where every person's right to harvest predominates) to purely private land rights, as in southern European countries, where forest owners claim ownership rights over specific forest externalities like wild mushrooms or other non-wood forest products. In Spain, national laws give exclusive rights over wild edible mushrooms to forest owners (Spanish Civil Code sections 353 to 355).

Secondly, wild mushroom harvesting has increased dramatically in many countries, with a growing number of harvesters pouring into forests, giving rise to problems of overexploitation and even extinction of species [24]. Arnolds [25] cited a depletion in mushroom diversity of more than $60 \%$ over a fifteen-year period in Germany. Jansen [26] expressed growing concern in the Netherlands over the extinction of Cantharellus cibarius Fr. In the Czech Republic, and Fellner [27] warned of the loss of common species such as Tricholoma portentosum (Fr.) in the north of the country. In Spain, García and Martinez-Peña [24] listed 23 species at risk from extinction (of the 153 species included in a red list of threatened species).

Thirdly, because it is a widely available resource with very low productivity per unit area, management is quite difficult, and imaginative management solutions are required $[28,29]$.

Fourth, uncertainty surrounding the expected harvest is very high due to enormous variability of production by seasons coupled with the short duration thereof [30]. It thus proves extremely difficult for policy-makers to implement a management system that suits harvesters' preferences.

Fifth, in recent years, there has been a change in harvesters' attitudes. Public demand for recreational harvesting of wild edible mushrooms has risen over the last two decades and currently affects all forest areas with mycological resources in many countries [31]. For example, in Castilla y León (Spain) over 50\% of the rural population harvest WEM [32] and in Finland this figure reaches $40 \%$ of the total population [33]. Harvesting has become an increasingly important part of family recreation time due to greater per-capita income in many countries, added to which is the strong self-consumption component of harvested products. The harvester profile has gradually shifted towards commercial harvesters who behave as production units selling their harvest in markets. Yet, both types of harvester have access to forests in order to collect, albeit pursuing different objectives. While the former seeks to maximize the level of utility, subject to budget constraints, the latter aims to maximize labour compensation from revenues minus the intermediate consumption and user cost of fixed capital. This also poses obstacles to managing the resource since permit systems should take this dichotomy into account as it is extremely difficult for policy-makers to distinguish between the two types of harvester. Depending on the amount of wild edible mushrooms collected, a given picker may behave differently and may sell the amount left over after self-consumption.

Finally, there are certain harvester features that cause major problems regarding wild edible mushroom management, such as the lack of producer (harvester) professionalization, illegal or undesirable harvesting practices, local mentality, reluctance to change, etc.

In view of all the above, many countries have taken legal and administrative measures to regulate by law the harvesting of wild edible mushrooms, like France (1974), Germany (1989), Luxembourg (1989), Italy (1993), Slovenia (1994), and Spain (2003). Yet perhaps the most advanced regulation is applied in countries like the USA, Italy, or Spain in the form of pilot projects involving the sale of permits that entitle harvesters to collect wild edible mushrooms. This is the case of the autonomous 
community of Castilla y Leon (Spain) where 370,000 hectares are controlled, and where the price of a harvesting permit is $€ 83$ per harvester per season (Unweighted arithmetic average of all kind of permits during the 2014 season). Another example in Europe is the province of Vicenza (Italy) where 93,000 hectares are controlled and harvesters pay $€ 49$ (Unweighted arithmetic average of all kind of permits during the 2010 season). A further example is that of the Gifford Pinchot National Forest (USA) where 530,000 hectares are controlled and harvesters pay $€ 57$ for a permit (Unweighted arithmetic average of all kind of permits during the 2014 season. Updated and converted into 2014 euros).

This new approach to managing the harvest of wild edible mushrooms focuses on the importance of setting a fee to harvest said natural resource. The need to know its demand function thus emerges in order to select a suitable range of prices in the same way that private markets perform. Setting an incorrect cost for permits could entail undesirable economic disorder, a common scenario in intervened markets.

To date, few studies have explored the valuation of mycological resources from a management perspective. Some works estimate the commercial aspects of wild edible mushrooms in order to integrate them into the forest's total value $[21,22,34,35]$. Yet, such studies prove insufficient as policy-making management tools, whereas examining said resource's demand function comes closer to the desired objective. A more suitable approach involves applying valuation techniques which can be used to estimate the consumer surplus obtained from harvesting. This is the case of Starbuck et al. [9], Frutos et al. [31] or Martinez de Aragón et al. [36], who employ revealed preference methods, or Brey et al. [37] who use stated preference methods.

All of these valuations could serve as a guide to policy-makers with regard to managing the harvesting of this resource. However, given the circumstances under which such studies were conducted, estimates of willingness to pay fail to respond to the objective of setting a market price for collecting. In other words, unlike in the present study, there are no estimation models that establish prices for wild edible mushroom harvesting permits and which explore the corresponding explanatory factors. The main objective of the present study is thus to investigate the willingness to pay (WTP) for wild edible mushroom harvesting (WEMH) in Andalusian forests (Spain) and to analyse the factors that influence harvesters' WTP. We estimate a single bounded WEMH model using a contingent valuation methodology.

\section{Materials and Methods}

\subsection{Study Site}

The Autonomous Community of Andalusia is located in the South of Spain (Figure 1). It is the most populated of the Spanish regions with 8,440,300 inhabitants (18\% of the national population) and is the second largest region in the country, covering $87,599 \mathrm{~km}^{2}$ (17.3\% of the whole country). It is the fourth largest European NUT-2 administrative area and is similar in size to countries like Portugal or Austria.

Andalusia forest stands cover an estimated area of nearly 4.4 million hectares, which is $50.1 \%$ of the total surface area of the region [38]. In addition, $67.6 \%$ of this area is covered by woody forest species. Moreover, an important part of the forest area of the region is occupied by dehesa stands $\left(18,126.5 \mathrm{~km}^{2}\right)$. In terms of vegetation type, hardwoods cover $70 \%$ of forest woody stands while $30 \%$ is comprised of conifers. The most common tree species are Quercus ilex L. followed by Pinus halepensis Mill. and Quercus suber L., which represent $84 \%$ of the total stock of forest stands in the region. In terms of ownership, most forest stands belong to private owners (73.3\%).

Andalusia has a wide variety of forest habitats and, consequently, a wide variety of wild mushrooms estimated at some 2505 species. Of these, thirty taxa are of commercial interest due to their high market value and include Cantharellus cibarius (Pers.) Fr., Boletus edulis Bull.:Fr., Amanita ponderosa Maleçon \& R. Heim, and even Tuber melanosporum Vittad. However, the most harvested species (by $51.2 \%$ of mushroom harvesters) is the saffron milk cap (Lactarius gr. deliciosus), 
while other important species include Pleurotus eryngii (DC.) Gillet (20\%), Amanita ponderosa (19.8\%), Agrocybe cylindracea (DC.) Gillet (19.8\%), and Agaricus campestris L. (18.5\%). Over half (53\%) of the pickers harvest several species, some even doing so at the same time (12\%). The annual mushroom harvest in Andalusia is thus estimated to be some 8790 tonnes of wild edible mushrooms valued at an annual $€ 43.2$ million in the $42,787 \mathrm{~km}^{2}$ of Andalusian forested area available for harvest [39].

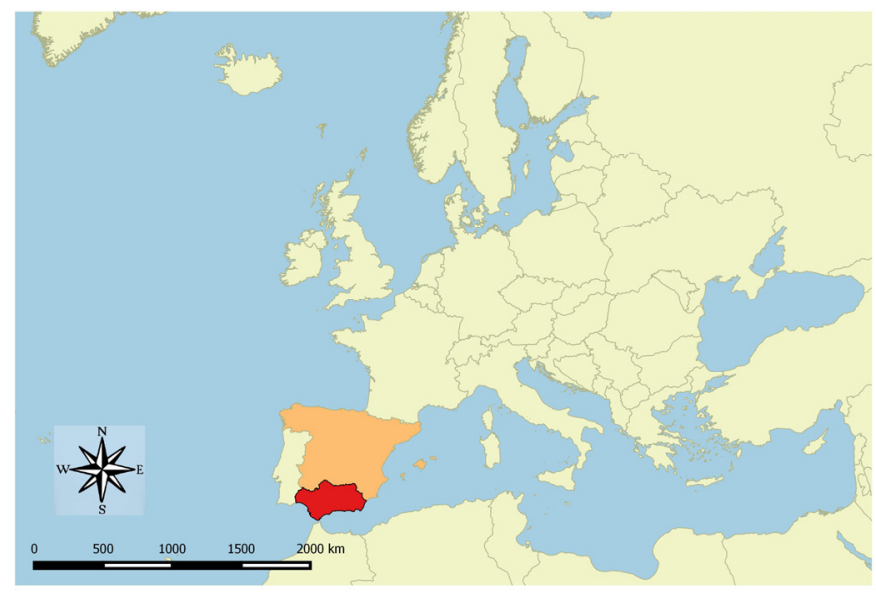

Figure 1. Andalusia location map.

\subsection{Model and Data}

\subsubsection{Model}

One major technical problem facing the implementation of such a management format is a lack of information for policy-makers concerning the harvesting demand function and, therefore, what price should be set for harvesters' permits when mushroom ownership rights belong to forest owners. In this sense, the contingent valuation method might serve to achieve such a goal.

Contingent valuation has been widely used to evaluate environmental attributes $[40,41]$ and there is extensive literature addressing the valuation of goods and services provided by forests [33,42-48], as well as other environmental attributes [49-60].

Although statistical information could be maximized using an open-ended WTP question, this ignores considerations of an individual's cognitive capacity [61]. Individuals often cannot simply state their WTP off the top of their heads [62]. The closed-ended dichotomous choice format comes closer to how individuals think and what they can answer [63]. Consequently, we used the dichotomous choice suggested by Hanemann [53]. This author defined the utility function for individual $j$ as follows:

$$
U_{j}(i, y)=V_{j}(i, y ; s)+\varepsilon_{j}
$$

where $\mathrm{U}($.$) denotes the indirect utility function, \mathrm{V}($.$) the systematic component, i$ the choice of accepting or rejecting the proposed payment, $y$ the level of income, $s$ a vector of socioeconomic characteristics, and $\varepsilon$ the random component. If the individual agrees to pay a certain amount, the change is accepted, which would give:

$$
\mathrm{V}(1, \mathrm{y}-\mathrm{bid} ; \mathrm{s})+\varepsilon_{1} \geq \mathrm{V}(0, y ; s)+\varepsilon_{0}
$$

where the bid is the individual's willingness to pay or a decrease in their level of income. Therefore, the probability of the researcher observing a positive response to the monetary amount bid is as follows:

$$
\begin{aligned}
& \operatorname{Pr}(i=1)=\operatorname{Pr}\left(\mathrm{V}(1, \mathrm{y}-\mathrm{bid} ; \mathrm{s})+\varepsilon_{1} \geq \mathrm{V}(0, y ; s)+\varepsilon_{0}\right) \\
& \operatorname{Pr}(i=1)=\operatorname{Pr}\left(\mathrm{V}(1, \mathrm{y}-\mathrm{bid} ; \mathrm{s})-\mathrm{V}(0, \mathrm{y} ; \mathrm{s}) \geq \varepsilon_{0}-\varepsilon_{1}\right)
\end{aligned}
$$


Thus, if the individual is willing to pay, the utility they provide the environmental attribute is higher than any other. If it defines $\eta=\varepsilon 0-\varepsilon 1$, and $\mathrm{F}($.$) the accumulative distribution function of \eta$, the probability of agreeing to pay for a change is equivalent to $F \eta(\Delta \mathrm{V})$, where $\Delta \mathrm{V}$ is the difference between the deterministic components of indirect utilities:

$$
\Delta \mathrm{V}=\mathrm{V}(1, \mathrm{y}-\mathrm{t} ; \mathrm{s})-\mathrm{V}(0, y ; \mathrm{s})
$$

The probability of accepting is thus defined as:

$$
\operatorname{Pr}(i=1 ; \Delta \mathrm{V} \geq \eta)=\mathrm{G}(\Delta \mathrm{V})
$$

where $G(\Delta V)$ is the accumulative density function. The most common case is the use of parametric estimates, where it is assumed that errors are normally distributed (Probit model) or logistically (Logit model) and the functions are approached through econometric fits of maximum likelihood techniques.

We assume the individual derives utility from engaging in wild edible mushroom harvesting and from monetary income. To represent harvesting, the variable willingness to pay (WTP) is introduced, where $\mathrm{WTP}_{j}=1$ if an individual $\mathrm{j}$ is willing to buy a permit at a given cost (Bid) and then harvest lawfully. $\mathrm{WTP}_{j}=0$ if they are not willing to pay this cost, and thus forfeit the right to collect. Harvester income is denoted by $y$, and other observable attributes of a harvester which might affect their preferences, such as socioeconomic characteristics like educational status $\left(\mathrm{s}^{1}{ }_{1}\right)$, gender $\left(\mathrm{s}^{1}{ }_{2}\right)$, family size $\left(\mathrm{s}^{1}{ }_{3}\right)$, and labour market situation $\left(\mathrm{s}^{1}{ }_{4}\right)$, which are denoted by the vector $\mathrm{s}^{1} \mathrm{p}(\mathrm{p}=1, \ldots, 4)$ or preferences related to harvesting experiences like harvesting yields $\left(\mathrm{s}^{2}{ }_{1}\right)$, harvesting travel distance $\left(\mathrm{s}^{2}{ }_{2}\right)$, commercial aspects $\left(\mathrm{s}^{2}{ }_{3}\right)$, and productive goodness $\left(\mathrm{s}^{2}{ }_{4}\right)$, which are denoted by the vector $\mathrm{s}^{2} \mathrm{k}$ $(\mathrm{K}=1, \ldots, 4)$ (see Table 1$)$.

\begin{tabular}{|c|c|c|c|}
\hline \multicolumn{4}{|c|}{ Categorical Variables } \\
\hline Variable & Description & Frequency (\%) & $n$ \\
\hline \multirow{6}{*}{ Bid } & $5 €$ & 23.3 & \multirow{6}{*}{176} \\
\hline & $10 €$ & 19.3 & \\
\hline & $20 €$ & 16.5 & \\
\hline & $50 €$ & 15.3 & \\
\hline & $70 €$ & 13.6 & \\
\hline & $90 €$ & 11.9 & \\
\hline \multirow{8}{*}{ Income $(y)^{*}$} & $600 €$ and less $=0$ & 17 & \multirow{8}{*}{176} \\
\hline & $600 €-1200 €=1$ & 40.3 & \\
\hline & $1200 €-1800 €=2$ & 16.5 & \\
\hline & $1800 €-2400 €=3$ & 21.6 & \\
\hline & $2400 €-3000 €=4$ & 0 & \\
\hline & $3000 €-3600 €=5$ & 2.3 & \\
\hline & $3601 €-4200 €=6$ & 2.3 & \\
\hline & $4200 €$ and above $=7$ & 0 & \\
\hline \multirow{8}{*}{$\begin{array}{l}\text { Educational status } \\
\qquad\left(\mathrm{s}^{1}{ }_{1}\right)\left({ }^{*}\right)\end{array}$} & Illiterate $=0$ & 7.4 & \multirow{8}{*}{176} \\
\hline & Primary school not finished $=1$ & 10.8 & \\
\hline & Primary school $=2$ & 35.8 & \\
\hline & High school not finished $=3$ & 7.4 & \\
\hline & High school $=4$ & 19.9 & \\
\hline & 3 -year degree $=5$ & 6.3 & \\
\hline & 5 -year degree $=6$ & 10.2 & \\
\hline & Doctorate degree $=7$ & 2.3 & \\
\hline
\end{tabular}

Table 1. Summary statistics for WEMHP (Wild Edible Mushroom Harvesting Permit) model variables. 
Table 1. Cont.

\begin{tabular}{|c|c|c|c|c|}
\hline \multicolumn{5}{|c|}{ Categorical Variables } \\
\hline Variable & Description & \multicolumn{2}{|c|}{ Frequency (\%) } & $n$ \\
\hline Gender $\left(s_{2}^{1}\right)$ & $\begin{array}{c}\text { Male }=0 \\
\text { Female }=1\end{array}$ & \multicolumn{2}{|c|}{$\begin{array}{l}46.6 \\
53.4\end{array}$} & 176 \\
\hline Non-working $\left(\mathrm{s}_{4}^{1}\right)$ & $\begin{array}{c}\text { Employed or unemployed }=0 \\
\text { Non-working }=1^{*}\end{array}$ & \multicolumn{2}{|c|}{$\begin{array}{l}55.1 \\
44.9\end{array}$} & 176 \\
\hline Sales $\left(\mathrm{s}_{3}^{2}\right)$ & $\begin{array}{c}\text { Picker does not sell mushrooms } \\
\text { collected }=0 \\
\text { Picker sells mushrooms collected }=1\end{array}$ & \multicolumn{2}{|c|}{94.9} & 176 \\
\hline \multicolumn{5}{|c|}{ Continuous Variables } \\
\hline Variable & Description & Mean & S.D. & $n$ \\
\hline Family size $\left(\mathrm{s}_{3}{ }_{3}\right)$ & Number of members of family unit & 2.4114 & 2.70841 & 176 \\
\hline $\begin{array}{l}\text { Harvesting yields } \\
\qquad\left(s^{2}{ }_{1}\right)\end{array}$ & $\begin{array}{l}\text { Amount of kilograms per hour of } \\
\text { wild mushrooms collected the } \\
\text { previous season }\end{array}$ & 0.8552 & 0.99576 & 176 \\
\hline $\begin{array}{l}\text { Harvesting travel } \\
\text { distance }\left(\mathrm{s}^{2}{ }_{2}\right)\end{array}$ & $\begin{array}{c}\text { Average distance (in } \mathrm{km} \text { ) travelled } \\
\text { between home and harvesting site in } \\
\text { the previous season }\end{array}$ & 24.568 & 635.924 & 176 \\
\hline $\begin{array}{c}\text { Productive } \\
\text { goodness }\left(\mathrm{s}^{2}{ }_{4}\right)\end{array}$ & $\begin{array}{l}\text { Harvester's assessment of the last } \\
\text { season based on wild edible } \\
\text { mushrooms collected (from } 0 \text { to } 10 \text { ) ** }\end{array}$ & 5.88 & 2.211 & 176 \\
\hline
\end{tabular}

* Pensioners, housewives, students, etc. Scales used regularly in Spanish studies; ${ }^{* *}$ The drafting of the question in the survey was as follows: How do you evaluate your wild edible mushroom harvesting in the 2009 season compared to other seasons? (If 0 , the value would be the worst situation and if 10 , the value would be the best situation). You can enter any value between 0 and 10.

Then, we specify the model as follows:

$$
\text { WTP } j=\beta 0+\beta_{1} b i d_{j}+\beta_{2} y_{j}+\beta_{3} s^{1}{ }_{1 j}+\beta_{4} s^{1}{ }_{2 j}+\beta_{5} s^{1}{ }_{3 j}+\beta_{6} s^{1}{ }_{4 j}+\beta_{7} s^{2}{ }_{1 j}+\beta_{8} s^{2}{ }_{2 j}+\beta_{9} s^{2}{ }_{3 j}+\beta_{10} s^{2}{ }_{4 j}+\varepsilon_{j}
$$

The parameters of the single-bounded Wild Edible Mushroom Harvesting Permit (WEMHP) model of discrete choice are estimated following [64]. The regression coefficients are estimated through an iterative maximum likelihood method [65] Goodness-of-fit measure $\left(R^{2}\right)$ is calculated following Nagelkerke [66] and the significance level of the single WEMHP model, using the Hosmer-Lemeshow test [67]. Finally, we estimate an individual's average maximum WTP following Naiga et al. [62]:

$$
\mathrm{WTP}=-\beta_{0} / \beta_{1}
$$

where $\beta_{0}$ is the intercept and $\beta_{1}$ the coefficient of the bid variable of the WEMHP estimated model.

\subsubsection{Data}

The survey population consisted of residents in Andalusia over 18 years of age [68]. A stratified random sample of 8083 individuals was selected (from 17,241 phone calls), with 4120 valid responses being obtained. The strata used was province (respondents' province of residence), urban (whether or not the person lived in a municipality of over 10,000 inhabitants), and forest (whether or not the person lived in a municipality with over $70 \%$ forested area), following information from official statistics and RECAMAN official documents $[38,68]$.

The survey instrument used in this study was a structured questionnaire comprising four parts which was administrated by telephone between January and May 2011 (in Andalusia the coverage of landline phones over households is above one). Professional interviewers gathered the information 
following the working protocol applied in such interviews. The first section provided an introduction and background to the survey. The goal was to ascertain whether respondents harvest wild edible mushrooms regularly, with the results showing that 462 individuals stated that they did so.

In these cases (if the respondent answered "no" then the interview was brought to an end), the following section asked questions about respondents' general attitudes toward mushroom collection and sought details of their harvesting activities over the previous season (2010), including their perception of the goodness of that season's harvesting. The third section involved a series of questions concerning the dichotomous choice contingent valuation harvesting management exercise. The questionnaire included an initial question aimed at ascertaining whether the interviewee was in the market or not and why not (if they were not), followed by a dichotomous question, and finally an open-ended WTP question. This bears out the similarity posited between the contingent valuation exercise and real markets [63], where consumers first decide whether or not to purchase the good before then making the second decision concerning whether they acquire it at a given price, as cheaply as possible (maximum willingness to pay). In the second question, six bids were selected-5, 10, 20, 50, 70, and 90 Euros-in the form of a permit for the whole harvesting season. Choice of these bids was made taking account of the most common prices for permits in other controlled areas of Spain. The percentage in which the initial bids were offered to each interviewee was calculated based on the responses offered by pickers in the initial pre-survey. The final section of the survey gathered socioeconomic information from each of the 462 respondents.

In the contingent valuation questionnaire, information was presented to respondents so that they could gain a full understanding of the hypothetical situation, thus reducing the rejection rate and allowing them to reveal their values as accurately as possible [69]. In the scenario, respondents were informed that the Regional Government was planning to collect funds from harvesters through payment of a harvesting permit, and they were told that such a forest management policy was common to other areas of Spain. Respondents were told that if harvesters were not willing to pay for the permit then they would not be allowed to harvest mushrooms in Andalusian forests. The questionnaire was conducted following the Blue Ribbon Panel recommendations [70].

\section{Results}

\subsection{Sample Characteristics}

The summary statistics of the data collected are provided in Table 1. A percentage of 11.23 of respondents indicated that they usually harvested wild edible mushrooms, with 38.01 percent showing a positive willingness to pay for a harvesting permit (176). These were people with a low income level $(y)$, most earning under $€ 1200$ a month. In regards to socio-economic characteristics, most also declared a low-level of education $\left(s^{1}{ }_{1}\right)$, having either not successfully completed or only completed primary education. Harvester gender $\left(\mathrm{s}^{1}{ }_{2}\right)$ was not a significant factor given that both (males and females) declared themselves to be harvesters at a similar population rate. The size of the family unit $\left(\mathrm{s}^{1}{ }_{3}\right)$ was approximately 2.4 individuals, half of these being non-working collectors $(44.9 \%)\left(\mathrm{s}^{1}{ }_{4}\right)$. With regards to previous mushroom harvesting experience, daily dedication was between two and three hours, harvesting an average of just over two kilograms of wild edible mushrooms per visit. This translates to a yield of $0.85\left(\mathrm{~s}^{2}{ }_{1}\right)$ kilograms per hour. In addition, over 90 percent of harvesters declared a travelled distance $\left(\mathrm{s}^{2}{ }_{2}\right)$ of less than $45 \mathrm{~km}$ from home, while 50 percent travelled less than five kilometres, with the average being $24 \mathrm{~km}$, thereby indicating that harvesting primarily represented a local activity. Only five percent of respondents harvested for commercial use $\left(\mathrm{s}^{2}{ }_{3}\right)$, indicating that most collected for self-consumption. Finally, in terms of productive goodness $\left(\mathrm{s}^{2}{ }_{4}\right)$, harvesters who collected in the previous season rated it as having been good, awarding it an average mark of 5.88 out of 10 . 


\subsection{Estimation of Willingness to Pay}

The estimation of willingness to pay, following Formula (8), was calculated using harvesters with a positive willingness to pay $(n=176)$. The major causes for zero response $(n=288)$ (i.e., rejecting any payment), are shown in Table 2 . In this survey, $22 \%$ of non-contributors argued that the regional government should provide financial support to preserve species of fungi. Twenty-one percent of non-paying respondents stated they would not contribute because they did not believe in management and conservation problems and that the funds would not therefore be used for environmental conservation of wild mushroom species. Eleven percent argued "I don't know/I do not wish to answer", and $46 \%$ said that they had no spare income to contribute and preferred not to pay and not to collect wild edible mushrooms.

Table 2. Respondents' reasons for not paying.

\begin{tabular}{ccc}
\hline Reasons for Not Paying & Number of Respondents & Percent \\
\hline $\begin{array}{c}\text { Regional government should provide } \\
\text { financial support to conserve fungi species } \\
\text { The funds would not be used for } \\
\text { environmental conservation of wild } \\
\text { mushroom species }\end{array}$ & 63 & 21.9 \\
$\begin{array}{c}\text { I don't know /I do not wish to answer } \\
\text { I prefer not to pay }\end{array}$ & 59 & 20.5 \\
\hline
\end{tabular}

The average estimated willingness to pay reached a value of $€ 22.61$ per harvester and season. Table 3 presents the frequency of the bids of the WTP responses for the WEMHP model. The most popular response was $€ 5$ per season (95\%) followed by $€ 10(88 \%)$. Results show that harvester behaviour is consistent with demand theory in terms of decreasing acceptance rates of bids. Nobody agreed to pay $€ 90$ per season for a permit.

Table 3. Frequency of willingness to pay (WTP) bids.

\begin{tabular}{cccc}
\hline Bids (in $\boldsymbol{\epsilon})$ & Frequency & Percent & Accept (\%) \\
\hline 5 & 41 & 23.3 & 95.1 \\
10 & 34 & 19.3 & 88.2 \\
20 & 29 & 16.5 & 65.5 \\
50 & 27 & 15.3 & 7.4 \\
70 & 24 & 13.6 & 4.2 \\
90 & 21 & 11.9 & 0.0 \\
\hline
\end{tabular}

\subsection{WEMHP Model: Factors Influencing Willingness to Pay}

The maximum likelihood estimates for the logistic regression model are presented in Table 4 . In the model, the null hypothesis is rejected at a 5\% level of significance, indicating that the variables in the logistic regression WEMHP model have a significant influence on respondents' WTP harvesting permits. The result of the $\mathrm{X}^{2}$ tests indicated that, on the whole, the estimated model proved satisfactory, and that the predictive capacity of the logit model was fairly accurate $(90.5 \%)$. Furthermore, the model's explanatory power is very high, with an $R^{2}$ value of over 0.8 . The intercept was significant at the $5 \%$ level and the coefficient of the bid at the $1 \%$ level with a negative effect on the probability of accepting, which is consistent with the model presented. In regards to socioeconomic variables, income (y) had a positive effect on respondents' WTP, which is consistent with demand theory. The null hypothesis that the coefficient estimates were equal to zero was rejected at a significance level of below $1 \%$. Not-working $\left(\mathrm{s}_{4}{ }_{4}\right)$ also had a positive and significant effect at the $10 \%$ level. This finding shows that people who declare that they are not in the labour market can devote more time to harvesting and, therefore, display a greater willingness to pay for a permit. Educational status $\left(s^{1}{ }_{1}\right)$, gender 
$\left(\mathrm{s}^{1}{ }_{2}\right)$, and family size $\left(\mathrm{s}^{1}{ }_{3}\right)$ did not affect respondents' $\mathrm{WTP}$, and the null hypotheses were not rejected. In regards to preferences related to harvesting experience variables, only sales $\left(\mathrm{s}^{2}{ }_{3}\right)$ had a significant influence on WTP level at the 1\% level. Willingness to pay was higher for commercial harvesters than for those who collected for recreational reasons. As a result, harvesters who dedicated all their harvest to self-consumption would be willing to pay less for a permit than harvesters who usually sell what they collect. Other factors, such as harvesting yields $\left(\mathrm{s}^{2}{ }_{1}\right)$, harvesting travel distance $\left(\mathrm{s}^{2}{ }_{2}\right)$, or productive goodness $\left(\mathrm{s}^{2}\right)$, did not prove significant at a $10 \%$ level.

Table 4. Estimation results of logistic regression WEMHP model (predicted variable WTP).

\begin{tabular}{cccc}
\hline Predictor Variables & $\beta$ & Std. Error & $p$-Value \\
\hline Intercept $\left(\beta_{0}\right)$ & $2.601^{* *}$ & 1.277 & 0.042 \\
Bid & $-0.115^{* * *}$ & 0.023 & $<0.001$ \\
Income $(y)$ & $1.094^{* * *}$ & 0.373 & 0.003 \\
Educational status $\left(\mathrm{s}^{1}{ }_{1}\right)$ & -0.086 & 0.208 & 0.680 \\
Gender $\left(\mathrm{s}^{1}{ }_{2}\right)$ & -0.111 & 0.623 & 0.858 \\
Family size $\left(\mathrm{s}^{1}{ }_{3}\right)$ & -0.053 & 0.136 & 0.695 \\
Non-working $\left(\mathrm{s}^{1}{ }_{4}\right)$ & $1.278^{*}$ & 0.753 & 0.090 \\
Harvesting yields $\left(\mathrm{s}^{2}{ }_{1}\right)$ & 0.070 & 0.285 & 0.806 \\
Harvesting travel distance $\left(\mathrm{s}^{2}{ }_{2}\right)$ & 0.002 & 0.003 & 0.559 \\
Sales $\left(\mathrm{s}^{2}{ }_{3}\right)$ & $4.419^{* * *}$ & 1.688 & 0.009 \\
Productive goodness $\left(\mathrm{s}^{2}{ }_{4}\right)$ & -0.217 & 0.144 & 0.805 \\
$-2 \operatorname{logl}$ & 72.671 & & \\
$R^{2}$ & 0.819 & & 0.020 \\
Hosmer-Lemeshow test $\left(\mathrm{x}^{2}\right)$ & 18.161 & & \\
Percentage of correct prediction & 90.5 & & \\
WTP & 22.61 & & \\
Number of observations (harvesters in & 176 & & \\
the contingent market) & & & \\
\hline
\end{tabular}

The description and the statistics of predictor variables are in Table $1 ;{ }^{* * *}$ Significant at 0.01 level, ${ }^{* *}$ significant at 0.05 level, * significant at 0.1 level.

\section{Discussion}

Although the estimated value is not comparable, it does resemble those calculated by other authors who apply similar techniques. Using the individual travel cost method version, Starbuck et al. [9] calculated the consumer surplus per day of non-commercial huckleberry and mushroom harvesters to be around $\$ 30$ in the Gifford Pinchot National Park in the State of Washington (USA). Applying the same version, Martinez de Aragón et al. [36] calculated a value of $€ 39$ per journey for a wild edible mushroom harvester in Solsones County (Spain). Using the zonal version of the model, Frutos et al. [31] obtain lower average estimations in the 1997-2005 period, specifically $€ 10$ per harvester per day in the Pinar Grande Mountain (Soria/Spain). Using a choice experiment, Brey et al. [37] calculated the willingness to pay for harvesting wild mushrooms in future afforested areas in Catalonia (Spain) to be $€ 5.77$ per year.

Our results thus show that the estimated willingness to pay is lower than the amount estimated by Starbuck et al., Martinez de Aragón et al., and Frutos et al. and higher than that estimated by Brey et al.

Our results could serve as a guide in wild edible mushroom management of many countries which use harvesting permits as an instrument. A simple analysis thereof seems to indicate that permit price in controlled areas is higher than estimated in the present research. Such is the case, for instance, in the autonomous community of Castilla y Leon (Spain), where the price of a harvesting permit is $€ 83$ per harvester and season. Another example in Europe is the province of Vicenza (Italy), where harvesters pay $€ 49$ per harvester One more example is that of the Gifford Pinchot National Forest (USA), where $€ 57$ is paid for a permit. 
Such a divergence could be explained because one aim of resource control might be to discourage certain harvesters, as is the case in Castilla y León (Spain), where the price of permits for harvesters who sell their produce is four-times higher than it is for those who collect for self-consumption. In this case, policy-makers are giving priority access to resources to harvesters who collect for recreational purposes over those who do so for profit. A similar case occurs in the Vicenza province, where the price of permits for non-residents is twice that of residents. Given that publicly owned forest is extremely important (up to $80 \%$ ), policy-makers should try to safeguard residents' property rights. This situation is more important in Castilla y León, where non-residents' permits are ten times more expensive than residents' permits. In this case, public ownership of forests in regulated areas is $100 \%$, with $85 \%$ being owned by the municipalities. This would mean giving priority access to resources to those who live in forested areas. This could be understood as a symptom of a long-term system of maintenance, since inhabitants could influence policy-makers' decisions with regard to resource management in upcoming local elections.

Furthermore, the main aim of controlling harvest regulation through the sales of permits should go beyond mere tax collection related to the supply and demand of the resource. It is true that such management could have a high potential for generating public income. For example, forest owners in Andalusia could raise some $€ 9.6$ million per season by selling permits. However, actual management experiences indicate that the final revenue obtained by controlling mycological resources remains scant. For example, in the case of Castilla y León (Spain), income amounts to $€ 0.4 /$ ha (one management costs have been discounted) This might be related to the harvest demand price-elasticity and price discrimination system applied in the sale of permits. In fact, nearly all harvesting permits are sold at the lowest prices and virtually none are sold at the highest prices. This could indicate a high harvest demand price-elasticity limiting the generation of revenue for forest owners.

\section{Conclusions}

Estimating a WEMHP model allows us to calculate the maximum willingness to pay for a permit through hypothetical management of wild edible mushroom harvesting. In the case of Andalusian forests, WTP reaches a value of $€ 22.61$ per harvester and season. These values depend on income, labour status, and commercial aspects of the mushroom harvest, and are independent of other socioeconomic characteristics such as educational status or gender. Furthermore, the results of this study also indicate that WTP does not depend on certain harvesting characteristics such as harvesting yield or productive goodness. This could thus be indicative of the importance of the recreational aspect of harvesting wild edible mushrooms, where WTP is independent of the final amount harvested.

Nevertheless, implications of this hypothetical harvesting WEM management go far beyond the tax-raising issues involved. Although it is true that tax revenue could aid such management by using funds to pay forest guards, reserve signs, trail maintenance, etc., taxation should not be the main target of harvesting WEM management via permits. Such management could possibly focus more closely on other natural resource management areas like hunting or fishing. In these cases, obtaining a permit is mandatory in most countries and such management has become generally accepted. Both the ruling authorities and the scientific community feel that this approach is necessary and the need for mandatory licences, most of which are obtained upon payment of a certain fee, is not challenged by anybody.

Wild edible mushroom management via payment of a permit should therefore focus more on achieving other goals, such as maintaining the species in the long term. Nevertheless, applying models such as the one presented here might help policy-makers to gain a clearer understanding of harvesting demand and, therefore, establish harvesting permits in a more efficient manner.

Other long-term dynamic effects that might also impact this kind of land management should also be taken into account. These include contributing towards current knowledge and research analysis of the information generated by WEM harvesting management, improved governance through implementing management models that are highly valued internationally, creating tourist appeal that 
might help generate much needed income in rural areas, and the effects of training and professionalism inherent in this type of management or positioning this type of pilot experience internationally. Current lines of research in these fields are expected to provide further key findings in the coming years that will help improve the management of this resource.

Acknowledgments: The authors wish to thank the Andalusian Regional Government and the Agency for Water and Environment in Andalusia for their financial support, and would also like to express their gratitude to the staff members María Isabel Martín and Luis Guzmán for helping in the field work in a group of agroforestry farms within the framework of the RECAMAN project (Contract NET165602). The authors gratefully acknowledge the valuable help received from these individuals and institutions and wish to stress that any shortcomings or errors in this research are the sole responsibility of the authors themselves.

Author Contributions: All authors designed the study, performed the analyses and interpreted the data. Pablo de Frutos wrote and reviewed the manuscript.

Conflicts of Interest: The authors declare no conflict of interest.

\section{References}

1. Oria De Rueda, J.A.; Martín-Pinto, P.; Olaizola, J. Bolete productivity of cistaceous scrublands in northwestern Spain. Econ. Bot. 2008, 62, 323-330. [CrossRef]

2. Roman, M.; Boa, E. The marketing of Lactarius deliciosus in northern Spain. Econ. Bot. 2006, 60, $284-290$. [CrossRef]

3. Sitta, N.; Floriani, F. Nationalization and globalization trends in the wild mushroom commerce of Italy with emphasis on porcini (Boletus edulis and allied species). Econ. Bot. 2008, 62, 307-322. [CrossRef]

4. Montoya, A.; Hernández, N.; Mapes, C.; Kong, A.; Estrada, A. The collection and sale of wild mushrooms in a community of Tlaxcala, Mexico. Econ. Bot. 2008, 62, 413-424. [CrossRef]

5. Perez, J.; Martínez, M.; Yescas, A.; Delgado, A.; Xoconostle, A.B. Wild mushroom markets in central Mexico and a case study at Ozumba. Econ. Bot. 2008, 62, 425-436. [CrossRef]

6. Christensen, M.; Bhattarai, S.; Devkota, S.; Larse, H.O. Collection and use of wild edible fungi in Nepal. Econ. Bot. 2008, 62, 12-23. [CrossRef]

7. Tibuhwa, D. Wild mushroom-An underutilized healthy food resource and income generator: Experience from Tanzania rural areas. J. Ethnobiol. Ethnomed. 2013, 9, 1. [CrossRef] [PubMed]

8. Dijk, H.; Van Onguene, N.A.; Kuyper, T.W. Knowledge and utilization of edible mushrooms by local populations of the rain forest of south cameroon. Ambio 2003, 32, 19-23. [CrossRef] [PubMed]

9. Starbuck, C.; Alexander, S.; Berrens, R.; Bohara, A. Valuing special forest products harvesting: A two-step travel cost recreation demand analysis. J. For. Econ. 2004, 10, 37-53. [CrossRef]

10. Turtiainen, M.; Saastamoinen, O.; Kangas, K.; Vaara, M. Picking of wild edible mushrooms in Finland in 1997-1999 and 2011. Silva Fennica 2012, 46, 569-581. [CrossRef]

11. Secco, L.; Vidale, E.; Pettenella, D. Comparing profitability and governance for recreational wild mushroom picking in forest and timber production. In Proceedings of the IUFRO International Symposium, Paris, France, 27-29 May 2010.

12. De Frutos Madrazo, P.; Martínez-Peña, F.; Esteban, S. Edible wild mushroom tourism as a source of income and employment in rural areas. The case of Castilla y León. For. Syst. 2012, 21, 81-98. [CrossRef]

13. Boa, E. Wild Edible Fungi: A Global Overview of Their Use and Importance to People; FAO: Rome, Italy, 2004.

14. Hosford, D.; Pilz, D.; Molina, R.; Amaranthus, M. Ecology and Management of the Commercially Harvested American Matsutake Mushroom; USDA: Portland, Oregón, USA, 1997; p. 68.

15. Palm, M.; Chapela, I.H. Mycology in Sustainable Development: Expanding Concepts, Vanishing Borders; Parkway Publishers Inc.: Winston-Salem, NC, USA, 1997; p. 297.

16. Bonet, J.A.; Palahí, M.; Colinas, C.; Pukkala, T.; Fischer, C.R.; Miina, J.; Martínez De Aragón, J. Modeling the production and species richness of wild mushrooms in pine forests of Central Pyrenees in north-eastern Spain. Can. J. For. Res. 2010, 40, 347-356. [CrossRef]

17. Martínez-Peña, F.; De-Miguel, S.; Pukkala, T.; Bonet, J.A.; Ortega-Martínez, P.; Aldea, J.; Martínez De Aragón, J. Yield models for ectomycorrhizal mushrooms in Pinus sylvestris forests with special focus on Boletus edulis and Lactarius group deliciosus. For. Ecol. Manag. 2012, 282, 63-69. [CrossRef] 
18. Aldea, J.; Martínez-Peña, F.; Díaz-Balteiro, L. Integration of fungal production in forest management using a multi-criteria method. Eur. J. For. Res. 2012, 131, 1991-2003. [CrossRef]

19. Aldea, J.; Martínez-Peña, F.; Romero, C.; Díaz-Balteiro, L. Participatory goal programming in forest management: An application integrating several ecosystem services. Forests 2014, 5, 3352-3371. [CrossRef]

20. Diaz-Balteiro, L.; Álvarez, A.; Oria De Rueda, J.A. Integración de la producción fúngica en la gestión forestal. Aplicación al monte "Urcido" (Zamora). Inv. Agrar.-Sist. Rec. For. 2003, 12, 5-19.

21. Palahi, M.; Pukkala, T.; Bonet, J.A.; Colinas, C.; Fischer, C.R.; Martinez De Aragón, J. Effect of the inclusion of mushrooms on the optimal management of even-aged Pine Stands of Catalonia. For. Sci. 2009, 55, 503-511.

22. Alexander, S.; Pilz, D.; Weber, N.; Brown, E.; Rockweel, V. Mushrooms, trees and money: Value estimates of commercial mushrooms and timber in the Pacific Northwest. Environ. Manag. 2002, 30, 129-141. [CrossRef] [PubMed]

23. Merlo, M.; Rojas, E. Public goods and externalities linked to the Mediterranean forests: Economic nature and policy. Land Use Policy 2000, 17, 197-208. [CrossRef]

24. García, A.; Martinez-Peña, F. Hacia una ordenación comercial del recurso micológico en Tierras Altas. In Proceeding of the XII World Forestal Meeting, Quebec, QC, Canada, 21-28 September 2002; Volume B, pp. 319-320.

25. Arnolds, A. Mycologysts and nature conservation. In Frontiers in Mycology; Hawksworth, D.L., Ed.; CAB International: Regensburg, Germany, 1990; pp. 243-264.

26. Jansen, A.E. How Netherlands mycologist started worried about declining of fungi. In Conservation of Fungi and Other Cryptograms in Europe; Jansen, A.E., Lawrynowicz, M.M., Eds.; Lodz Society of Sciences and Arts: Lodz, Poland, 1990; pp. 17-23.

27. Fellner, R. Air pollution and mycorrizal fungi in Central Europe. In Fungi of Europe: Investigation, Recording and Conservation; Pegler, D.N., Boddy, L., Ing, B., Kirk, P.M., Eds.; Royal Botanic Gardens: Kew, UK, 1993; pp. 239-250.

28. Canton, A.; Pettenella, D. Family forest owners' motivations in forest management activities: A case study in Recoaro Terme municipality (north-east Italy). For. J. Silv. For. Ecol. 2010, 7, 44-57. [CrossRef]

29. García, J. Regulación de la recolección de hongos silvestres comestibles. Modelo Myas-RC. In Manual Para la Gestión del Recurso Micológico; Junta de Castilla y León: León, Spain, 2011; pp. 106-144.

30. De Frutos Madrazo, P.; Peña, F.M.; Laleona, S.E. Propuesta de ordenación comercial de los aprovechamientos micológicos a través de lonjas agrarias. Rev. Esp. Estud. Agrosoc. Pesq. 2008, 217, 73-103.

31. Frutos, P.D.; Peña, F.M.; Martínez, P.O.; Esteban, S. Estimating the social benefits of recreational harvesting of edible wild mushrooms using travel cost methods. For. Syst. 2009, 18, 235-246. [CrossRef]

32. Martinez-Peña, F.; Giner, M.; Lucas, J.A. Primeros resultados del estudio del aprovechamiento micológico a partir de encuestas en la zona MYAS (Soria): Recolección, micoturismo y ordenación del recurso. In Proceedings of the I Congreso Nacional de Micología Forestal Aplicada, Soria, Spain, 7-9 May 2003.

33. Tyrväinen, L. Economic valuation of urban forest benefits in Finland. J. Environ. Manag. 2002, 62, 75-92. [CrossRef] [PubMed]

34. Cai, M.; Pettenella, D.; Vidale, E. Income generation from wild mushrooms in marginal rural areas. For. Policy Econ. 2011, 13, 221-226. [CrossRef]

35. Voces, R.; Diaz-Balteiro, L.; Alfranca, O. Demand for wild edible mushrooms: The case of Lactarius deliciosus in Barcelona (Spain). J. For. Econ. 2012, 18, 47-60. [CrossRef]

36. Martínez de Aragón, J.; Riera, P.; Giergiczny, M.; Colinas, C. Value of wild mushrooms picking as an environmental service. For. Policy Econ. 2011, 13, 419-424. [CrossRef]

37. Brey, R.; Riera, P.; Mogas, J. Estimation of forest values using choice modeling: An application to Spanish forests. Ecol. Econ. 2007, 64, 305-312. [CrossRef]

38. Díaz Balteiro, L.; Alejandro Caparrós, A.; Campos, P.; Almazán, E.; Ovando, O.; Álvarez, A.; Voces, R.; Romero, C. Economía y selviculturas de los montes de Andalucía. In Economía Privada de Productos Leñosos, Frutos Industriales, Bellota, Pastos Y El Servicio del Carbono en Los Sistemas Forestales de Andalucía; Campos, P., Díaz-Balteiro, L., Eds.; Memorias científicas de RECAMAN. Editorial CSIC: Madrid, Spain, 2015; Volume 2, Memoria 2.3. 
39. Martínez-Peña, F.; Aldea, J.; Frutos, P.; Campos, P. Renta ambiental de la recolección pública de setas silvestres en los sistemas forestales de Andalucía. In Biodiversidad, Usos del Agua Natural Y Recolección de Setas Silvestres en Los Sistemas Forestales de Andalucía; Campos, P., Díaz-Balteiro, M., Eds.; Memorias científicas de RECAMAN. Editorial CSIC: Madrid, Spain, 2015; Volume 2, Memoria 2.3.

40. Cummings, R.G.; Cox, L.; Freeman, A.M. General methods for benefits assessments. In Benefits Assessments: The State of the Art; Bentkover, J., Covello, V., Mumpower, J., Eds.; Springer: Dordrecht, The Netherlands, 1986; pp. 161-191.

41. Mitchell, R.C.; Carson, R.T. Using Surveys to Valuing Public Goods. The Contingent Valuation Method; Resources for the Future: Washington, DC, USA, 1989.

42. Boyle, K.; Johnson, F.; McCollum, D. Anchoring and adjustment in single-bounded contingent-valuation questions. Am. J. Agric. Econ. 1997, 5, 1495-1500. [CrossRef]

43. Hackl, F.; Prukner, G.J. On the gap between payment card and closed-ended CVM-answers. AppL. Econ. 1999, 31, 733-742. [CrossRef]

44. Clinch, J.P.; Murphy, A. Modeling winners and losers in contingent valuation of publics goods: Appropiate welfare measures and econometric analysis. Econ. J. 2001, 111, 420-443. [CrossRef]

45. Cameron, T.A.; Poe, G.L.; Ethier, R.G.; Schulze, W.D. Alternative non-market value elicitation methods: Are underlying preferences the same? J. Environ. Econ. Manag. 2002, 44, 391-425. [CrossRef]

46. Loomis, J.; González-Caban, A.; Hesseln, H. Multicultural evaluation of the performance of contingent valuation for forest fire prevention. Contemp. Econ. Policy 2004, 22, 407-419. [CrossRef]

47. Han, F.; Yan, Z.; Wang, H.; Xu, X. Estimating willingness to pay for environment conservation: A contingent valuation study of Kanas Nature Reserve, Xinjiang, China. Environ. Monit. Assess. 2011, 180, 451-459. [CrossRef] [PubMed]

48. Sumukwo, J.; Adano, W.R.; Kiptui, M.; Cheserek, G.J.; Kipkoech, A.K. Valuing of natural insurance demand for non-timber forest products in South Nandi, Kenya. J. Emerg. Trends Econ. Manag. 2013, 4, 89-97.

49. Berrens, R.P.; Jenkins-Smith, H.; Bohara, A.K.; Silva, C.L. Further investigation of voluntary contribution contingent valuation: Fair share, time of contribution and respondent uncertainty. J. Environ. Econ. Manag. 2002, 44, 144-168. [CrossRef]

50. Bishop, R.C.; Heberlein, T.A. Measuring values of extra-markets goods: Are indirect measures biased? Am. J. Agric. Econ. 1979, 61, 926-930. [CrossRef]

51. Bonini, N.; Biel, A.; Gärling, T.; Karlsson, N. Influencing what money is perceived to be worth: Framing and priming in contingent valuation studies. J. Econ. Psychol. 2002, 23, 655-663. [CrossRef]

52. Breffle, W.; Morey, E.R.; Lodder, T.S. Using contingent valuation to estimate a neighborhood's willingness to pay to preserve undevelopment urban land. Urban Stud. 1998, 35, 715-727. [CrossRef]

53. Hanemann, W.M. Welfare evaluations in contingent valuation experiments with discrete responses. Am. J. Agric. Econ. 1984, 66, 332-341. [CrossRef]

54. Hanley, N. Using contingent valuation to value environmental improvements. Appl. Econ. 1988, 20, 541-549. [CrossRef]

55. Loomis, J.B. Improving validity experiments of contingent valuation methods. Results of efforts to reduce the disparity of hypothetical and actual willingness to pay. Land Econ. 1996, 72, 450-461. [CrossRef]

56. Ready, R.C.; Malzubris, J.; Senkane, S. The relationship between environmental values and income in a transition economy. Surface water quality in Latvia. Environ. Dev. Econ. 2002, 7, 147-156. [CrossRef]

57. Surendram, A.; Sekar, C. An economic analysis of willingness to pay for conserving biodiversity. Int. J. Soc. Econ. 2010, 37, 637-648. [CrossRef]

58. Wu, P.; Huang, C.L. Actual averting expenditure versus stated willingness to pay. Appl. Econ. 2001, 33, 277-283. [CrossRef]

59. Yamazaki, S.; Rust, S.; Jennings, S.; Lyle, J.; Frijlink, S. Valuing recreational fishing in Tasmania and assessment of response bias in contingent valuation. Aust. J. Agric. Res. Econ. 2013, 57, 193-213. [CrossRef]

60. Yoo, S.H.; Kwak, S.J.; Kim, T.Y. Modeling willingness to pay responses from dichotomous choice contingent valuation surveys with zero observations. Appl. Econ. 2001, 33, 523-529. [CrossRef]

61. Hanemann, W.M.; Kanninen, B. The Statistical Analysis of Discrete-Response cv Data; Working Paper No. 798; California Agricultural Experiment Station: Davis, CA, USA, 1996.

62. Naiga, R.M.; Woodward, R.; Aiew, W. Willingness to pay for reduced risk of foodborne illness: A nonhypothetical field experiment. Can. J. Agric. Econ. 2006, 54, 461-475. [CrossRef] 
63. Kriström, B. Spike models in contingent valuation models. Am. J. Agric. Econ. 1997, 79, 1013-1023. [CrossRef]

64. Jennings, D.E. Outliers and residual distributions in logistic regression. J. Am. Stat. Assoc. 1986, 81, 987-990. [CrossRef]

65. Norusis, M. SPSS 13.0 Statistical Procedures Companion; Prentice Hall, Inc.: Upper Saddle-River, NJ, USA, 2004.

66. Nagelkerke, N.J.D. A note on the general definition of the coefficient of determination. Biometrika 1991, 78, 691-692. [CrossRef]

67. Hosmer, D.W.; Lemeshow, S. Applied Logistic Regression, 2nd ed.; John Wiley and Sons: New York, NY, USA, 2000.

68. Spanish Statistics Office (SSO). Statistical Use of the Continuous Municipal Register Files. 2010. Available online: http:/ / www.ine.es (accessed on 15 November 2010).

69. Nape, S.; Frykblom, P.; Harrison, G.; Lesley, J. Hypothetical bias and willingness to accept. Econ. Lett. 2002, 1,1-8. [CrossRef]

70. Arrow, K.; Solow, R.; Portney, P.R.; Leamer, E.E.; Radner, R.; Schuman, H. Report of the NOAA panel on contingent valuation. Fed. Regist. 1993, 58, 4601-4614.

(C) 2016 by the authors; licensee MDPI, Basel, Switzerland. This article is an open access article distributed under the terms and conditions of the Creative Commons Attribution (CC-BY) license (http://creativecommons.org/licenses/by/4.0/). 